\title{
Achieving Soil Security through Biobased Residues
}

\author{
Emmanuel Badewa and Maren Oelbermann* \\ School of Environment, Resources \& Sustainability, University of Waterloo, Canada
}

*Corresponding author: Maren Oelbermann, Professor, School of Environment, Resources and Sustainability, University of Waterloo, Canada.

Received Date: June 05, 2020

Published Date: June 16, 2020

\begin{abstract}
The challenges of environmental degradation caused by the human demands and climate change have led to soil degradation. As a way forward, the adoption of water, energy, food, and soil security are viewed as a long-term solution to address these problems. This mini review presents an overview of the capacity of enhancing soil health through the integration of biobased residues (BBR) as a sustainable soil amendment. The perspective of how the use of BBR fits within the concept of soil health and soil security, and how it relates to sustainability indicators was also evaluated. Furthermore, the use of BBR was assessed using criteria considered important for soil and crop performance, and an overall evaluation of sustainable outcomes. We concluded that the application of BBR to agriculture offered a sustainable approach to address current environmental challenges, including the diversion of landfill organic wastes to agricultural land.
\end{abstract}

Keywords: Organic amendment; Soil, Sustainability; Climate change; Soil organic matter; Food security; Soil health

\section{Introduction}

The degradation of soil and the concurrentgeneration of organic waste is increasing as the world's population is equally on the rise. Annually, $\sim 12$ billion hectares of land are lost to soil erosion and degradation with an approximate cost of \$2.3US trillion (USD) [1]. This startling rate of soil degradation and soil erosion has resulted in short-and long-term sustainability concerns for food, energy, and water [2-4]. To address these challenges, the water-energy-food (WEF) nexus was developed. The WEF nexus addresses resource and development challenges that improve our understanding of the complex interactions among multiple resource systems [57]. However, the adoption of the WEF nexus has aggravated the degradation of soil [8] and there is no evidence that the WEF nexus is sufficient to address concerns surrounding sustainability [7]. Also, the WEF nexus does not to support future resources required by a rising global population including the conservation of soil resources [8]. However, a healthy soil determines our capacity to produce food, fodder, fiber, and energy [8]. Hence, there is a need to consider and explore ways to maintain or improve long-term soil health and soil security using sustainable approaches.

In addition to the WEF nexus, intensive agroecosystem management practices are another major cause of global soil degradation. Therefore, it is pertinent to adopt sustainable approaches to agroecosystem management to maintain soil, crop and livestock productivity immediately and in the long-term. Conventional agroecosystem management practices include a reliance on agrochemicals and mineral fertilizers that have compromised water quality and led to soil acidification [9-10]. Currently, $70 \%$ of global $\mathrm{N}_{2} \mathrm{O}$ emissions, a greenhouse gas with a 310 times greater warming capacity than $\mathrm{CO}_{2}$, is derived from agriculture's reliance on nitrogen $(\mathrm{N})$-derived mineral fertilizers [3]. Additionally, intensive tillage practices have led to soil erosion which is paralleled by a loss of soil organic matter (SOM) [9-10]. To date, $\sim 40 \%$ of the global croplands are experiencing significant soil erosion and degradation $[4,11]$. Due to the severity of global 
soil degradation, the United Nations (UN) declared 2015 as the International Year of Soils (http://www.fao.org/soils-2015/en/) to discuss possible ways of reversing and mitigating the rapid degradation of soil $[10,12]$. Furthermore, the International Union of Soil Scientists declared the years from 2015 to 2024 as the international decade of soils (https://www.iuss.org/internationaldecade-of-soils/) as a continuation of the accomplishments achieved during the International Year of Soils in 2015. These actions resulted in the integration of soil into 13 of the $17 \mathrm{UN}$ Sustainable Development Goals (SDG) [13].

Our current understanding of various soil management practices and how these affect soil processes remains limited [3]. This is because soil is a complex ecosystem comprised of abiotic and biotic components that interact with each other and this is further complicated by interactions across the soil-crop-atmosphere continuum. In addition, various approaches to agroecosystem management including the type of crop planted and how/if crops are rotated, the quantity and type of amendments added to the soil (e.g. manure, mineral fertilizer), and residue management (e.g. complete, partial or no crop residue removal, residue input from sources outside of the farm) further add to this complexity [14]. However, the UN-FAO is promoting a new pathway to soil conservation based on sustainable agricultural intensification [15]. This approach integrates a high level of productivity with the maintenance of a wide range of soil processes, which are critical to help maintain soil health under the current and projected increase for demand in food, fiber, fodder and fuel [15]. The key concept of sustainable agricultural intensification includes the efficient use of natural resources via ecological interactions in the soil-plantatmosphere continuum [16].

The concept of sustainable agricultural intensification also promotes the integration of the bioeconomy using organic residues that have been diverted from waste management processes (e.g. landfills, sewage), and the forestry, fishery, and agricultural industries [17]. The bioeconomy therefore uses biological knowledge plus the resources that directly or indirectly originate from plants, animals, or microorganisms for commercial and industrial purposes [17]. The biological resources used in the bioeconomy are referred to as biobased residues (BBR) that transferred from biobased production chains to agricultural land [18]. Current approaches to agriculture already include, to some extent, the use of BBR as a soil amendment; although with variation of the level of integration $[10,19]$. Despite some potential limitations of BBR like biosolids, the application of BBR is currently promoted as a way forward to a more sustainable approach to agriculture with the potential to enhance soil health, biodiversity and climate change mitigation via carbon (C) sequestration $[20,21]$. For example, in the Canadian Province of Ontario, organic amendments like biosolids are provided at no cost to agricultural producers [22,23]. However, their application to agricultural soil has limitations and application is not permitted on steeply (>9\%) sloped land, frozen soil or soil with moderate to slow permeability, it also requires a $100 \mathrm{~m}$ buffer zone between the area of application and aquatic ecosystems [22,23]. However, biosolids that have been treated (minimal heavy metal and pathogen content) and meet requirements set by the Federal Fertilizers Act can be sold as a fertilizer (e.g. LysteGro; https://lystek.com/solutions/lystegrobiofertilizer/) to agricultural producers [24]. Other BBR including composted food waste (CFW), anaerobic digestate (AD) as well as biosolids (BS) and have the capacity to meet the ecologically based, agronomic and soil management criteria necessary to achieve soil security and sustainability. For example, composted food waste had the greatest positive long-term effect on crop yield compared to a fertilizer-only control [25]. For example, Drury et al. [25] found that CFW increased yields by $11.3 \%$ compared to the fertilized control over a 10-year period. While biosolids contain high quantities of organic $\mathrm{C}$, nitrogen $(\mathrm{N})$, phosphorus $(\mathrm{P})$ and other micronutrients including sulfur $(\mathrm{S})$, calcium $(\mathrm{Ca})$ and iron (Fe) [26], they also contain heavy metals and pathogens allowing their application only on a 5-year rotation [27]. Anaerobic digestates improve soil physical characteristics (reduced erosion, improved soil structure and increased water retention) and enhance microbial activity (increased biomass and $\mathrm{N}$ mineralization rates) compared to soils amended with manure or mineral fertilizer [28,29]. For example, Odlare et al. [28] found that over a 4-year study, AD increased the $\mathrm{N}$ mineralization capacity and the proportion of active soil microorganisms compared to mineral fertilizer.

\section{Biobased Residues in Relation to Sustainable Development}

The UN developed 17 SDGs based on several sustainability development indicators (SDIs). The SDIs that encapsulate BBR include, but not limited to, a growing global population, environmental pollution, overflowing landfills, excessive use of agrochemicals, soil degradation and climate change. Since 1987, the Brundtland Sustainability Report noted that SDIs can be used effectively to solve global challenges affecting our resource systems [30]. This has resulted in the development of SDI's that are relevant, easy to understand, reliable and based on accessible data [31]. In addition, there is a school of thought that soil should be the basic criteria of ecological design after which plants, animals and people should be upwardly considered [34]. This suggests the need to assess the effect of human activity on living organism and their environment through a critical evaluation of areas involving soil health, food security, technological advancement, globalization, economic growth, and the environment [32-33].

Using BBR as a soil amendment has the capacity to address the underlying issues related to humans, the waste they produce and their application to agricultural soil to ensure food security (Figure 1). For example, the waste produced by humans has led to our current crisis of landfills reaching capacity in addition to leaching and methane emissions. However, the organic portion of materials 
deposited in Landfills can be recycled directly to agricultural soil or indirectly by first undergoing industrial processes, thereby supporting the bioeconomy [17]. Organic amendments derived directly or indirectly from BBR, when used as an agricultural soil amendment, improves soil health, enhances crop productivity, and mitigates climate change via $\mathrm{C}$ sequestration and lowering greenhouse gas (GHG) emissions. A co-benefit of this approach is its capability to ensure the long-term security of food through enhanced soil health which also generates resilience in agroecosystems when adapting to a changing climate.

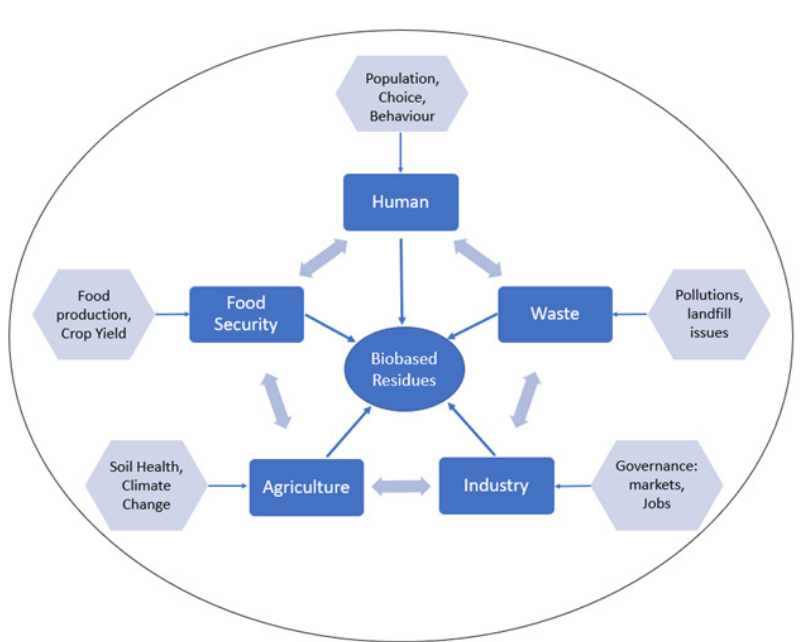

Figure 1: The interconnections between sustainable indicators and biobased residues (BBR) as a potential solution for soil security.

The success of this approach is strongly dependent on quantitative research at a regional scale to help determine how effective BBRs are in their stability and efficacy in soil and their response to a changing climate. For example, do soils amended with BBRs respond differently to freeze-thaw events in temperate biomes than soils amended with mineral fertilizer and/or livestock manure? The impact of BBR on GHG emissions during the growing season or under freeze-thaw has produced variable results [35-37]. There are only a few systematic studies that have evaluated the impact of BBR on the GHG balance, using a lifecycle approach, and soil health [18]. Paustian et al. [38] noted that the constraint to soil health is largely dependent on the amendment emission's lifecycle and the limitation of BBR application in cold climates. Furthermore, Urra et al. [39] found that high application rates and odour causes a negative reaction towards BBRs. Therefore, there is need to explore and carry out in depth investigations on BBR of various origins and how these affect soil health, $C$ sequestration and GHG emissions under a changing climate. Knowledge mobilization, by integrating information gained by researchers and industry and its translation to agricultural produces and general society, will play a significant role in helping to understand that the integration of BBR to agroecosystems is a sustainable approach for the environment, people and the economy.

\section{The Assessment of Biobased Residues for Sustainability Outcomes}

\section{Biobased residues: choice of agricultural practice and sustainability}

The paradigm of sustainable intensification practices and the incorporation of BBR within this model as a sustainable and complementary approach to agroecosystem management will help curb our current reliance on mineral fertilizers [20]. Since the 1950s, the Green Revolution (GR) has served as a successful symbol of agricultural intensification but it has also caused reliance on high-yielding hybrid crop varieties, irrigation infrastructure, use of agrochemicals such as herbicides and the reliance on mineral fertilizers to improve yield on the most impoverished soils [40]. However, the GR has limitations because it relies on management approaches requiring materials (e.g. seed, fertilizer) that are not readily accessible for the majority of the global population [40,41]. The approach promoted by the GR is also not environmentally sustainable over the long-term due to the reliance on agrochemicals, hybridized crops and the use of crops from outside of their native growing range $[40,41]$. Although, our understanding of BBRs and the interactions they cause in agricultural soil remains limited [18], such knowledge is essential as it will determine the capacity of BBR to contribute to soil and food security on a global scale (Figure 2). In contrast to GR agriculture, agroecology where ecological processes are integrated into agricultural production systems, provides a sustainable approach to soil health and food security $[20,42]$ and it includes the use of BBR as part of routine agroecosystem management practices. Agricultural practices that incorporate BBR are also influenced by economic, social, and political factors [43]. For example, Leopold [44] noted that agricultural producers typically choose agroecosystem management practices that provide the greatest yield and therefore the highest economic gain. Thus, the rationale of agricultural producers, which is readily influenced by social and cultural factors, is critical, in incorporating BBR within already existing agroecosystem management practices [45]. Additionally, if an agricultural producer views him or herself as a steward of the land, the choice will tend towards the adoption of sustainable agroecosystem management practices that often include BBR [34]. 


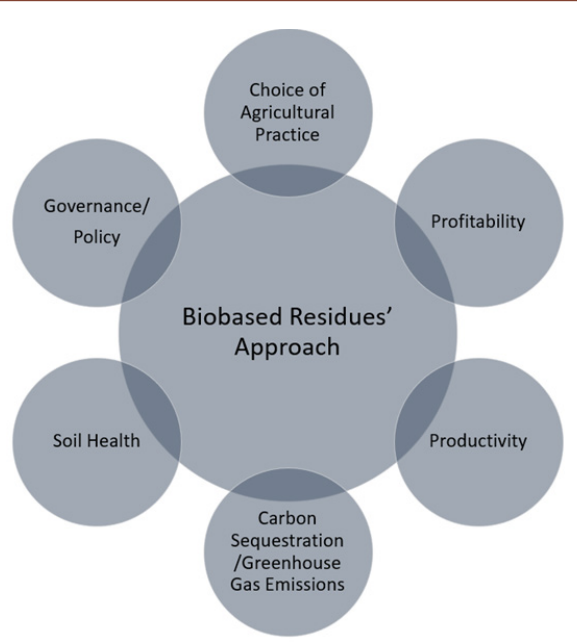

Figure 2: Factors for the assessment of the sufficiency of biobased residues (BBR) for soil health and socioecological sustainability.

\section{Governance and policy}

Apart from the multiple agroeconomic and ecological benefits of BBR, there is a need for policy reforms that will support and recognize the role of BBR in maintaining soil health and food security. Various governmental and non-governmental organizations as well as industry have developed significant interest in integrating environmental waste incorporated with technology to enhance environmental sustainability including the mitigation of GHGs [4648]. Frequently, technological innovations that have incorporated BBR occur on a local scale using local feedstocks. Localized technology can be used to produce a nutrient rich soil amendment that can in turn improve soil health, enhance crop yield, and reduce GHG and non-GHG emissions including ammonia and dinitrogen [48-50]. Although we are gradually gaining knowledge on the best approaches for sustainable agroecosystem management, this is not equally paralleled by advances in governance and policy. For example, de Molina [51] noted that the movement of adopting sustainable agricultural practices stems largely from nongovernmental organizations supported by academic institutions that are responsible for producing the required knowledge and technology. This means that there is a need for the development of agricultural policies that will motivate agricultural producers to adapt the use of BBR and for the general public to accept the use of BBR in the production of food, fodder, fiber and fuel. Garini et al. [43] argued that "public policies are important because it can motivate the adoption of innovative farming practices". For instance, agricultural policies of the European Union (EU) acknowledge the complexity of socioecological systems and their dependence on sustainable agricultural practices to ensure food security [52]. This approach has also increased the value of agricultural land [52]. This infers that agricultural development and adoption of sustainable agroecosystem management practices, including the use of BBR, is dependent on the development and implementation of policies.

\section{Carbon sequestration and greenhouse gas emissions}

The use of organic manures in agriculture, based on crop and soil type, began more than 2000 years ago [53]. Historically, the application of BBR was based on the need to recycle nutrients back to the soil without a conscious effort to maintain soil organic matter (SOM) levels or sequester C, but instead it was based on the premise of maintaining crop productivity. For example, organic manures such as human sewage, and animal and plant residues were applied to agricultural soil in China for the benefit of crop growth [54]. In Medieval times, the application of animal manure on agricultural land was to replace the materials removed by crop cultivation [55]. By the end of the $18^{\text {th }}$ Century, the use of organic amendments on agricultural soil began to shift and was nearly phased-out by the 1950s when mineral fertilizers were introduced as a more effective way to increase crop productivity [56-58]. This approach, however, has led to a steep decline in SOM reserves while at the same time increased the accumulation of GHG in the atmosphere. This was based on the assumption that SOM will always be available, and the accumulation atmospheric GHG and climate change are extraneous $[41,59]$. Instead the focus was on ensuring ample supply and availability of $\mathrm{N}$ since it is the crucial factor in ensuring crop productivity $[41,59]$. However, the increasing accumulation GHG in the atmosphere can be attributed to both organic amendments and mineral fertilizer used in agricultural production systems [45,61]. To address these challenges, there are several efforts such as the 4 per mile initiative (http://4p1000.org) whose focus is to increase SOM content by $0.4 \%$ per year. This initiative targets long-term sequestration and storage of $\mathrm{C}$ in soil [62], while simultaneously addressing climate change, and help improve soil fertility and crop productivity [63]

\section{Soil health}

Due to the importance of SOM on soil processes that in turn influence soil health, there has been a rising interest in understanding how amendment addition other than crop residues, manure and fertilizer, influence soil health and enhance crop productivity. The use of amendments like biochar and BBR have the potential to enhance soil health and improve crop yield. Soil health, the capacity of soil to perform agricultural and environmental functions such as crop and biomass productivity [59], can be 
effectively assessed by evaluating physical, chemical, and biological soil characteristics referred to as soil health indicators (SHIs) [64]. The most frequently evaluated SHIs include SOM content, aggregate stability, microbial biomass and activity, soil $\mathrm{C}$ and $\mathrm{N}$ dynamics and how the transformation of these nutrients relates to climate change [59]. One of the main foci of SHI is to maintain or enhance levels of SOM [41]. Over the past 80 years, the role of SOM as an ecosystem component, and its role in maintaining soil health and agricultural productivity, has been recognized. More recently, the role of SOM in mitigating climate change due to its capacity to sequester $\mathrm{C}$ has also been realized [60]. However, soil cultivation and agricultural production has been linked to declining reserves of SOM, which has contributed $116 \mathrm{Pg}$ of $\mathrm{C}$ to the atmosphere [65]. In addition, the currently rapid expansion of agriculture in areas such as the Brazilian Amazon is causing a continual loss of SOM and emission of C-based GHG to the atmosphere [66]. Consequently, it is important to consider SOM from a sustainable perspective and that this can be achieved using BBR. Integrating BBR with enhancing SOM levels can also help with C trading or C offset policies [67].

\section{Productivity}

The focus on increasing grain yield rather than maintaining soil health has led to a global concern that SI should incorporate BBR into the modern crop production system. Due to the current and projected increase of the global population $[8,68]$, cereal production must increase by $25-50 \%$, from current production levels, by 2050 in order to generate sufficient food [69]. However, the cost of increased agricultural production is soil degradation and ultimately its contribution to climate change $[8,70]$. An analysis by Wise [68] also concluded that large expanse of land is needed to increase crop production to support a growing global population. Therefore, there is a critical need to encourage sustainable agricultural intensification practices that includes the incorporation of BBR to maintain soil health while ensuring crop productivity without further conversion of undisturbed ecosystems to agriculture. Hatfield et al. [8] illustrated how the interaction of increased crop productivity is dependent on soil under sustainable intensification (SI). In their paper, they also suggested on how to improve and adopt agronomic techniques and increase management intensity that recognizes soil resources management [8].

\section{Profitability}

One of the foundations of BBR is its capacity to contribute to the bioeconomy. Given that organic residues are readily available, and the projection of these waste materials will continue to increase and paralleled by an increase in the global population, there is a social and environmental need to recycle these materials $[27,72]$. This, however, also requires the establishment of infrastructure including storage and co-composting facilities [73-74]. Biobased residues can be readily integrated into the bioeconomy and its use can be expanded beyond agriculture to include the production of energy and other materials [75-76]. For example, the European bioeconomy in 2016 contributed a revenue of $€ 2.1$ trillion (EUR) in addition to 18.3 million jobs, comprising 9\% of the total EU workforce [77-78]. This implies that BBR has the capacity to provide numerous benefits and at multiple scales that encourages sustainable development at a global scale.

\section{Conclusions and Recommendations}

The water-energy-food nexus is not sufficient to address issues surrounding environmental sustainability since it does not integrate the conservation of soil resources into its framework. The importance of soil as part of a sustainable approach to agriculture is slowly gaining attention of policy developers because of its role in ensuring food security. This acknowledgement is due to the international efforts by the UN-FAO that designated the year 2015 to soil, the International Union of Soil Science that designated 2015-2024 as the decade of soils, and the 4 per mille movement initiated in France in 2015. These initiatives include the integration of BBR as a sustainable approach to agroecosystem management practices that help maintain soil health and ensure the long-term security of food. In this mini review, we outlined the relationship between BBR and SDIs and how the integration of these leads to a sustainable approach to agricultural land management practices. We also emphasize the need for quantitative research on the impact of BBRs on soil health, especially under a changing climate. To effectively explore the impact of integrating BBRs into agricultural soil, it is pertinent to establish multiple cross-regional and replicated research plots over the medium-term ( $>5$ years) and long-term ( $>10$ years). This help address modern agricultural and environmental challenges in a global bioeconomy.

\section{Acknowledgment}

We thank the University of Waterloo for providing infrastructure that supported the production of this manuscript. We thank the Ontario Ministry of Agriculture and Environment and Sam Halloran (Lystek International) for providing financial assistance for our field study on biobased residues that helped stimulate the ideas presented in this mini review. We also thank the reviewers and the editors for their input to help improve this manuscript.

\section{Conflict of Interest}

No conflict of interest.

\section{References}

1. Bouma J (2015) Reaching out from the soil-box in pursuit of soil security. Soil science and plant nutrition 61(4): 556-565.

2. Nkonya E, Gerber N, Baumgartner P, von Braun J, De Pinto A, et al. (2011) The economics of desertification, land degradation, and drought toward an integrated global assessment. ZEF-Discussion Papers on Development Policy (150), pp. 196.

3. Lal R (2012) Climate change and soil degradation mitigation by sustainable management of soils and other natural resources. Agricultural Research 1(3): 199-212.

4. De Long C, Cruse RM, Wiener J (2015) The soil degradation paradox: compromising our resources when we need them most. Sustainability 7: 866-879. 
5. Foran T (2015) Node and regime: Interdisciplinary analysis of waterenergy-food nexus in the Mekong region. Water Alternatives 8(1).

6. Wolfe ML, Ting KC, Scott N, Sharpley A, Jones JW, et al. (2016) Engineering solutions for food-energy-water systems: it is more than engineering. Journal of Environmental Studies and Sciences 6(1): 172-182.

7. Albrecht TR, Crootof A, Scott CA (2018) The Water-Energy-Food Nexus: A systematic review of methods for nexus assessment. Environmental Research Letters 13(4): 043002.

8. Hatfield JL, Sauer TJ, Cruse RM (2017) Soil: The forgotten piece of the water, food, energy nexus. Academic Press. In Advances in Agronomy 143: 1-46.

9. Lal R (2010) Enhancing eco-efficiency in agro-ecosystems through soil carbon sequestration. Crop Sci 50: 120-131.

10. Gomiero T, Pimentel D, Paoletti MG (2011) Is there a need for a more sustainable agriculture? Critical reviews in plant sciences 30(1-2): 6-23.

11. Reynolds JF, Maestre FT, Kemp PR, Stafford-Smith DM, Lambin E (2007) Natural and human dimensions of land degradation in drylands: causes and consequences. In Terrestrial ecosystems in a changing world, Springer, Berlin, Heidelberg, pp. 247-257.

12. UN (United Nations) (2013) Draft Resolution Submitted by the ViceChair of the Committee, Ms. Farrah Brown (Jamaica), on the Basis of Informal Consultations on Draft Resolution A/C.2/68/L.21, United Nations General Assembly: Washington, DC, USA.

13. Keesstra SD, Bouma J, Wallinga J, Tittonell P, Smith P, et al. (2016) The significance of soils and soil science towards realization of the United Nations Sustainable Development Goals. Soil 2: 111-128.

14. Helming K, Daedlow K, Hansjürgens B, Koellner T (2018) Assessment and Governance of Sustainable Soil Management. Sustainability 10(12): 4432 .

15. Rockström J, Williams J, Daily G, Noble A, Matthews N, et al. (2017) Sustainable intensification of agriculture for human prosperity and global sustainability. Ambio 46(1): 4-17.

16. Tittonell P (2014) Ecological intensification of agriculture-sustainable by nature. Current Opinion in Environmental Sustainability 8: 53-61.

17. Birner R (2018) Bioeconomy concepts. In: Lewandowski I (ed.) Bioeconomy: shaping the transition to a sustainable, biobased economy. Springer Nature Switzerland, pp. 17-38.

18. Ho A, Ijaz UZ, Janssens TK, Ruijs R, Kim SY, de Boer W, et al. (2017) Effects of bio-based residue amendments on greenhouse gas emission from agricultural soil are stronger than effects of soil type with different microbial community composition. Gcb Bioenergy 9(12): 1707-1720.

19. Lampkin NH, Pearce BD, Leake AR, Creissen H, Gerrard CL, et al. (2015a) The role of agroecology in sustainable intensification. ORC Bulletin. No. 119 - Autumn/Winter.

20. Lampkin NH, Pearce BD, Leake AR, Creissen H, Gerrard CL, et al. (2015b) The role of agroecology in sustainable intensification. Report for the Land Use Policy Group. Organic Research Centre, Elm Farm and Game \& Wildlife Conservation Trust.

21. Luo G, Li L, Friman VP, Guo J, Guo S, Shen Q et al. (2018) Organic amendments increase crop yields by improving microbe-mediated soil functioning of agroecosystems: A meta-analysis. Soil Biology and Biochemistry 124: 105-115.

22. Wessuc (2018) Winter Spreading and Biosolids- Sewage Biosolids. Waste management service in Brant, Ontario.

23. OMAFRA (2020) Sewage biosolids- managing urban nutrients responsibly for crop production. Ministry of Agriculture, Food and Rural Affairs, Ontario, Canada.

24. Halloran S (2020) Do you have a question about Biosolids or Organics? Lystek.org.
25. Drury CF, Reynolds WD, Yang XM, Tan CS, Guo X, et al. (2014) Influence of compost source on corn grain yields, nitrous oxide and carbon dioxide emissions in southwestern Ontario. Canadian Journal of Soil Science 94(3): 347-355.

26. Wang H, Brown SL, Magesan GN, Slade AH, Quintern M, et al. (2008) Technological options for the management of biosolids. Environmental Science and Pollution Research-International 15(4): 308-317.

27. Quilty JR, Cattle SR (2011) Use and understanding of organic amendments in Australian agriculture: a review. Soil Research 49(1): $1-26$.

28. Odlare M, Pell M, Svensson K (2008) Changes in soil chemical and microbiological properties during 4 years of application of various organic residues. Waste management 28(7): 1246-1253.

29. Boldrin A, Andersen JK, Møller J, Christensen TH, Favoino E (2009) Composting and compost utilization: accounting of greenhouse gases and global warming contributions. Waste Management \& Research 27(8): 800-812.

30. Brundtland GH (1987) Brundtland Report. Our Common Future. Comissão Mundial.

31. Sustainable Measures (2010) Sustainability Indicators 101: Indicators for sustainability.

32. Living Planet Report (2014) World wildlife (WWF) Living Planet Report 2014

33. Dryzek J (2013) The Politics of the Earth. Environmental Discourses (Oxford).

34. Orr DW (2002) The Nature of Design: Ecology, Culture, and Human Intention, Oxford University Press, p. 29.

35. Thangarajan R, Bolan NS, Tian G, Naidu R, Kunhikrishnan A (2013) Role of organic amendment application on greenhouse gas emission from soil. Science of the Total Environment 465: 72-96.

36. Liu X, Wang Q Qi Z, Han J, Li L (2016) Response of $\mathrm{N}_{2} \mathrm{O}$ emissions to biochar amendment in a cultivated sandy loam soil during freeze-thaw cycles. Scientific reports 6: 35411.

37. Chantigny MH, Bittman S, Larney FJ, Lapen D, Hunt DE, et al. (2019) A multi-region study reveals high overwinter loss of fall-applied reactive nitrogen in cold and frozen soils. Canadian Journal of Soil Science 99(2): 126-135.

38. Paustian K, Lehmann J, Ogle S, Reay D, Robertson GP, et al. (2016) Climate-smart soils. Nature 532(7597): 49-57

39. Urra J, Alkorta I, Garbisu C (2019) Potential Benefits and Risks for Soil Health Derived from the Use of Organic Amendments in Agriculture. Agronomy 9(9): 542.

40. Borlaug N (1970) Norman Borlaug - Nobel Lecture.

41. Altieri MA, Nicholls CI (2012) Agroecology scaling up for food sovereignty and resiliency. In Sustainable agriculture reviews. Springer, Dordrecht, pp. 1-29.

42. Gliessman SR (2014) Agroecology: the ecology of sustainable food systems. CRC press.

43. Garini CS, Vanwindekens F, Scholberg JMS, Wezel A, Groot, JC (2017) Drivers of adoption of agroecological practices for winegrowers and influence from policies in the province of trento, italy. Land Use Policy 68: 200-211.

44. Leopold A (1970) A sand county almanac: With other essays on conservation from Round River. Outdoor Essays \& Reflections.

45. Hathaway MD (2016) Agroecology and permaculture: addressing key ecological problems by rethinking and redesigning agricultural systems. Journal of Environmental Studies and Sciences 6(2): 239-250. 
46. Amon B, Kryvoruchko V, Amon T, Zechmeister-Boltenstern S (2006) Methane, nitrous oxide and ammonia emissions during storage and after application of dairy cattle slurry and influence of slurry treatment. Agriculture, ecosystems \& environment 112(2-3): 153-162.

47. Saletnik B, Zaguła G, Bajcar M, Tarapatskyy M, Bobula G, et al. (2019) Biochar as a Multifunctional Component of the Environment-A Review. Applied Sciences 9(6): 1139.

48. Adegbeye MJ, Reddy P, Kanth R, Obaisi AI, Elghandour MM, et al. (2020) Sustainable agriculture options for production, greenhouse gasses and pollution alleviation, and nutrient recycling in emerging and transitional nations-An overview. Journal of Cleaner Production 242: 118319.

49. Meier S, Curaqueo G, Khan N, Bolan N, Cea M, et al. (2017) Chickenmanure-derived biochar reduced bioavailability of copper in a contaminated soil. Journal of Soils and Sediments 17(3): 741-750.

50. Yamashita T, Shiraishi M, Yokoyama H, Ogino A, Yamamoto-Ikemoto $\mathrm{R}$, et al. (2019) Evaluation of the Nitrous Oxide Emission Reduction Potential of an Aerobic Bioreactor Packed with Carbon Fibres for Swine Wastewater Treatment. Energies 12(6): 1013.

51. De Molina MG (2013) Agroecology and politics. How to get sustainability? About the necessity for a political agroecology. Agroecology and Sustainable Food Systems 37(1): 45-59.

52. Lomba A, Strohbach M, Jerrentrup JS, Dauber J, Klimek S, et al. (2017) Making the best of both worlds: Can high-resolution agricultural administrative data support the assessment of High Nature Value farmlands across Europe? Ecological indicators 72: 118-130.

53. Mang H, (2015) How the Chinese are turning human waste into 'black gold'.

54. Beaton J (2009) History of fertilizer. Efficient Fertilizer Use Manual, Mosaic Back to Basics, Plymouth, Minnesota, USA.

55. Wild A (1988) Historical. In: Wild, A. (Ed.), Russell's Soil Conditions and Plant Growth, eleventh ed. Longman Scientific \& Technical, Harlow, Essex, UK, pp. 1-30.

56. Allison RV (1944) The Original Field Plot Studies at Rothamsted 1. Soil Science Society of America Journal 8(C): 6-11.

57. Dyke GV (1993) John Lawes of Rothamsted. Pioneer of Science, Farming and Industry. Hoos Press, Harpenden, UK.

58. Goss MJ, Tubeileh A, Goorahoo D (2013) A review of the use of organic amendments and the risk to human health. In Advances in agronomy 120: 275-379.

59. Lal R (2011) Soil health and climate change: an overview. In Soil health and climate change (pp. 3-24). Springer, Berlin, Heidelberg.

60. Schlesinger WH, Amundson R (2019) Managing for soil carbon sequestration: Let's get realistic. Global change biology 25(2): 386-389.

61. Yadav V, Karak T, Singh S, Singh AK, Khare, P (2019) Benefits of biochar over other organic amendments: Responses for plant productivity (Pelargonium graveolens L.) and nitrogen and phosphorus losses Industrial Crops and Products 131: 96-105.

62. Chenu C, Angers DA, Barré P, Derrien D, Arrouays D, et al. (2019) Increasing organic stocks in agricultural soils: Knowledge gaps and potential innovations. Soil and Tillage Research 188: 41-52.
63. Lal R (2008) Carbon sequestration, Philos. T Roy Soc B 363: 815-830.

64. Allen DE, Singh BP, Dalal RC (2011) Soil health indicators under climate change: a review of current knowledge. In Soil health and climate change, Springer, Berlin, Heidelberg, pp. 25-45.

65. Sanderman J, Hengl T, Fiske GJ (2017) Soil carbon debt of 12,000 years of human land use. Proceedings of the National Academy of Sciences 114(36): 9575-9580.

66. Assad ED, Pinto HS, Martins SC, Groppo JD, Salgado PR, et al. (2013) Changes in soil carbon stocks in Brazil due to land use: paired site comparisons and a regional pasture soil survey. Biogeosciences 10: 6141-6160.

67. Murphy BW (2015) Impact of soil organic matter on soil properties-a review with emphasis on Australian soils. Soil Research 53(6): 605-635.

68. Wise TA (2013) Can we feed the world in 2050. A scoping paper to assess the evidence. Global Development and Environment Institute Working Paper, (13-04). Tufts University. 38 p.

69. Smith P, Gregory PJ, Van Vuuren D, Obersteiner M, Havlík P, et al. (2010) Competition for land. Philosophical Transactions of the Royal Society B: Biological Sciences 365(1554): 2941-2957.

70. Tilman D, Balzer C, Hill J, Befort BL (2011) Global food demand and the sustainable intensification of agriculture. Proceedings of the national academy of sciences 108(50): 20260-20264

71. Campbell BM, Thornton P, Zougmoré R, Van Asten P, Lipper L (2014) Sustainable intensification: What is its role in climate smart agriculture? Current Opinion in Environmental Sustainability 8: 39-43.

72. Maiti SK, Ahirwal J (2019) Ecological Restoration of Coal Mine Degraded Lands: Topsoil Management, Pedogenesis, Carbon Sequestration, and Mine Pit Limnology. In Phytomanagement of Polluted Sites, Elsevier, pp. 83-111.

73. Alvarenga P, Mourinha C, Farto M, Santos T, Palma P, et al. (2015) Sewage sludge, compost and other representative organic wastes as agricultural soil amendments: Benefits versus limiting factors. Waste management 40: 44-52.

74. El-Naggar A, Lee SS, Rinklebe J, Farooq M, Song H, et al. (2019) Biochar application to low fertility soils: a review of current status, and future prospects. Geoderma 337: 536-554.

75. Tsagaraki E, Karachaliou E, Delioglanis L, Kouzi E (2017) D2.1 Bio-based products and applications potential. (Q-PLAN)

76. European Commission (2020) Bioeconomy policy: Policy background, strategy and contribution to the Commission's political agenda of bioeconomy policy.

77. BECOTEPS (2011) The European Bioeconomy in 2030: Delivering sustainable growth by addressing the Grand Societal Challenges.

78. Piotrowski S, Carus M, Carrez D (2016) European Bioeconomy in figures. Commissioned by Bio-based Industries Consortium. 